\title{
Pengembangan Ekonomi Kreatif Bidang Kuliner Khas Daerah Jambi
}

\author{
Novita Sari \\ Dosen Fakultas Ekonomi dan Bisnis Universitas Jambi \\ Email: arkaanraja@yahoo.co.id
}

\begin{abstract}
ABSTRAK
Istilah ekonomi kreatif pertama kali diperkenalkan oleh John Howkins di tahun 2001. Diawali pada tahun 1997 dimana saat itu Howkins menyadari akan adanya sebuah perubahan industri ekonomi yang berdasar pada kreativitas masyarakat. Ekonomi kreatif adalah gagasan baru sistem ekonomi yang menempatkan informasi dan kreativitas manusia sebagai faktor produksi yang paling utama. Perkembangan ekonomi kreatif di Indonesia didukung oleh arahan Presiden RI bahwa ekonomi kreatif harus menjadi tulang punggung ekonomi Indonesia. Hal ini juga didukung oleh kebijakan pemerintah mengenai meningkatkan pertumbuhan ekonomi yang inklusif dan berkelanjutan, antara lain melalui pengembangan ekonomi kreatif dan peningkatan kapasitas inovasi dan tekhnologi (Perpres no.2 Tahun 2015 - RPJMN 2015-2019). Ruang lingkup industri kreatif meliputi 16 sub sektor (industri) dan salah satunya adalah kuliner. Kuliner adalah salah satu komponen identitas suatu daerah. Di Provinsi Jambi, industri kuliner mengalami perkembangan yang sangat pesat. Provinsi Jambi adalah salah satu Provinsi di Indonesia yang memiliki berbagai makanan khas daerah, yang dalam perkembangannya semakin tenggelam dengan kehadiran kuliner modern. Sebagai bagian dari identitas Provinsi Jambi, sudah menjadi kewajiban kita untuk melestarikan kuliner khas daerah ini. Berdasarkan hal tersebut, maka perlu dilakukan penelitian mengenai upaya apa saja yang bisa dilakukan guna mengembangkan ekonomi kreatif kuliner khas daerah Jambi ini. Penelitian ini diharapkan nantinya dapat menganalisis faktor apa saja menjadi kendala dan bagaimana cara mengatasi kendala-kendala tersebut, serta apa saja yang perlu dilakukan agar kuliner khas Jambi ini agar tidak punah dan dapat mengalami perkembangan yang berarti.
\end{abstract}

\section{Kata Kunci : Ekonomi Kreatif, Sub Sektor Kuliner, Makanan Khas Daerah}

\section{PENDAHULUAN}

Istilah ekonomi kreatif pertama kali diperkenalkan oleh John Howkins di tahun 2001. Diawali pada tahun 1997 dimana saat itu Howkins menyadari akan adanya sebuah perubahan industri ekonomi yang berdasar pada kreativitas masyarakat. Ekonomi kreatif adalah gagasan baru sistem ekonomi yang menempatkan informasi dan kreativitas manusia sebagai faktor produksi yang paling utama. Ide merupakan barang mahal dalam ekonomi kreatif, karena ideide yang kreatif inilah yang akan mendorong terciptanya inovasi-inovasi yang kemudian menjadi solusi baru dan produk baru, dimana ini merupakan jawaban selama ini atas masalah minimnya kualitas produk yang sesuai dengan kebutuhan pasar.

Dimulai pada tahun 2006 di mana Presiden Susilo Bambang Yudhoyono menginstruksikan untuk mengembangkan ekonomi kreatif di Indonesia. Proses pengembangan ini diwujudkan pertama kali dengan pembentukan Indonesian Design Power oleh Departemen Perdagangan untuk membantu pengembangan ekonomi kreatif di Indonesia. Untuk mewujudkan Indonesia 
Kreatif, mulai tahun 2009 diadakan Pekan Produk Kreatif dan Pameran Ekonomi Kreatif yang berlangsung setiap tahunnya.

Konsep ekonomi kreatif merupakan sebuah konsep ekonomi di era ekonomi baru yang mengintensifkan informasi dan kreativitas dengan mengandalkan ide dan stock of knowledge dari Sumber Daya Manusia (SDM) sebagai faktor produksi utama dalam kegiatan ekonominya. Struktur perekonomian dunia mengalami transformasi dengan cepat seiring dengan pertumbuhan ekonomi, dari yang tadinya berbasis Sumber Daya Alam (SDA) sekarang menjadi berbasis SDM, dari era pertanian ke era industri dan informasi.

John Howkins dalam bukunya The Creative Economy: How People Make Money from Ideas pertama kali memperkenalkan istilah ekonomi kreatif. Beliau mendefinisikan ekonomi kreatif sebagai the creation of value as a result of idea. Howkins menjelaskan ekonomi kreatif sebagai "kegiatan ekonomi dalam masyarakat yang menghabiskan sebagian besar waktunya untuk menghasilkan ide, tidak hanya melakukan hal-hal yang rutin dan berulang. Karena bagi masyarakat ini, menghasilkan ide merupakan hal yang harus dilakukan untuk kemajuan."

Dalam cetak biru Pengembangan Ekonomi Kreatif Indonesia 2009-2015, ekonomi kreatif didefinisikan sebagai "Era baru ekonomi setelah ekonomi pertanian, ekonomi industri, danekonomi informasi, yang mengintensifkan informasi dan kreativitas dengan mengandalkan ide dan pengetahuan dari sumber daya manusia sebagai faktor produksi utama dalam kegiatan ekonominya."

Departemen Perdagangan Republik Indonesia (2008) merumuskan ekonomi kreatif sebagai upaya pembangunan ekonomi secara berkelanjutan melalui kreativitas dengan iklim perekonomian yang berdaya saing dan memiliki cadangan sumber daya yang terbarukan. Definisi yang lebih jelas disampaikan oleh UNDP (2008) yang merumuskan bahwa ekonomi kreatif merupakan bagian integratif dari pengetahuan yang bersifat inovatif, pemanfaatan teknologi secara kreatif, dan budaya.

Dapat disimpulkan bahwa Ekonomi kreatif adalah gagasan baru sistem ekonomi yang menempatkan informasi dan kreativitas manusia sebagai faktor produksi yang paling utama. Disini ide merupakan barang mahal karena ide-ide yang kreatif inilah yang akan mendorong terciptanya inovasi-inovasi yang kemudian menjadi solusi baru dan produk baru, dimana ini merupakan jawaban selama ini atas masalah minimnya kualitas produk yang sesuai dengan kebutuhan pasar. Perkembangan ekonomi kreatif di Indonesia didukung oleh arahan Presiden RI bahwa ekonomi kreatif harus menjadi tulang punggung ekonomi Indonesia. Hal ini juga didukung oleh kebijakan pemerintah mengenai meningkatkan pertumbuhan ekonomi yang inklusif dan berkelanjutan, antara lain melalui pengembangan ekonomi kreatif dan peningkatan kapasitas inovasi dan tekhnologi (Perpres No.2 Tahun 2015-RPJMN 2015-2019)

Ekonomi kreatif sangat tergantung kepada modal manusia (human capital / intellectual capital, ada juga yang menyebutnya creative capital). Ekonomi kreatif membutuhkan sumberdaya manusia yang kreatif, mampu melahirkan berbagai ide dan menterjemahkannya ke dalam bentuk barang dan jasa yang bernilai ekonomi. Proses produksinya bisa saja mengikuti kaidah ekonomi industri, tapi proses ide awalnya adalah kreativitas)

Ruang lingkup industri kreatif meliputi 16 sub sektor (industri) dan salah satunya adalah kuliner. Persoalan makan bukan lagi sekadar urusan mengisi perut, melainkan juga menjadi 
hal menarik dari perspektif seni dan gaya hidup. Fenomena inilah yang ditangkap oleh Badan Ekonomi Kreatif yang dibentuk setahun lalu untuk memilih kuliner sebagai salah satu lokomotif menggerakkan subsektor lain dalam industri kreatif. Langkah ini diharapkan dapat mendorong pendapatan masyarakat secara langsung dan mampu meningkatkan pertumbuhan ekonomi. (Posman, 2016)

Kuliner di Indonesia sebenarnya sudah lama menorehkan jejaknya, yakni sebagai bagian dari sejarah perjalanan bangsa ini. Kuliner tidak hanya berbicara tentang makanan, bahanbahan, dan cara memasaknya, tetapi juga etika di meja makan, tata cara menghidangkan makanan, hingga kondisi dapur, seperti yang dipermasalahkan perempuan Belanda dalam buku De Hollandsche Tafel in Indie terbitan tahun 1900.

Kuliner bisa menjadi identitas suatu suku, kota, bahkan bangsa. Dalam perjalanannya, kuliner terkadang dijadikan alat untuk menilai status sosial seseorang. Kuliner pun bisa bercerita tentang sejarah peradaban dan menjadi salah satu daya tarik pariwisata. Lewat kuliner, kita bisa bercerita mengenai panjang lebar tentang keindonesian kita.

Industri kuliner di Provinsi Jambi mengalami perkembangan yang sangat pesat. Hal ini dibuktikan dengan semakin banyaknya pilihan yang tersedia, mulai dari makanan lokal sampai dengan makanan manca negara, disajikan di restaurant, café sampai dengan kaki lima, dengan kisaran harga yang sangat bervariasi. Provinsi Jambi adalah salah satu Provinsi di Indonesia yang memiliki berbagai makanan khas daerah, yang dalam perkembangannya semakin tenggelam dengan kehadiran kuliner modern. Banyak faktor yang memungkinkan hal ini terjadi, salah satunya adalah pengolahan yang masih sangat tradisional.

Provinsi Jambi memiliki berbagai kuliner khas daerah yang sangat unik dan menggugah selera. Mulai dari lauk pauk sampai dengan jajanan pasar. Provinsi Jambi banyak memiliki kuliner khas seperti Tempoyak, Gulai Umbut, Gulam itam, Ikan tepek, Malbi, Maksuba, Engkak Ketan, Ipuk-ipuk, dll. Saat ini, kulier tersebut hanya dapat ditemui di kalangan tertentu dan dinikmati dalam waktu tertentu saja. Sebagai bagian dari identitas Provinsi Jambi, sudah menjadi kewajiban kita untuk melestarikan kuliner khas daerah ini. Berdasarkan hal tersebut, maka perlu dilakukan penelitian mengenai upaya apa saja yang bisa dilakukan guna mengembangkan ekonomi kreatif kuliner khas daerah Jambi ini. Penelitian ini diharapkan nantinya dapat menganalisis faktor apa saja menjadi kendala dan bagaimana cara mengatasi kendala-kendala tersebut, serta apa saja yang perlu dilakukan agar kuliner khas Jambi ini agar tidak punah dan dapat mengalami perkembangan yang berarti.

\section{Tujuan dan Manfaat Penelitian}

\section{Tujuan Penelitian}

Berdasarkan rumusan masalah dalam penelitian ini maka tujuan penelitian ini adalah sebagai berikut :

a) Untuk melakukan upaya pengembangan ekonomi kreatif kuliner khas daerah Jambi.

b) Untuk melestarikan kuliner khas daerah Jambi. 


\section{Manfaat Penelitian}

Setelah selesainya kegiatan penelitian ini, maka akan diperoleh keluaran berupa data dan informasi mengenai upaya apa saja yang perlu dilakukan dalam pengembangkan kuliner khas daerah Jambi melalui penerapan ekonomi kreatif.

\section{METODE PENELITIAN}

\section{Objek Penelitian}

Objek penelitian merupakan sasaran untuk mendapatkan suatu data. Sugiyono (2011), menyatakan bahwa objek penelitian adalah suatu atribut atau sifat atau nilai dari orang, objek atau kegiatan yang mempunyai variasi tertentu yang ditetapkan oleh peneliti untuk dipelajari dan kemudian ditarik kesimpulannya. Objek penelitian dalam penelitian ini adalah kuliner khas daerah jambi yaitu ipuk-ipuk dan padamaran.

\section{Metode Pengumpulan Data}

Berdasarkan sumbernya, data dapat dibedakan menjadi data primer dan data sekunder.

a) Data Primer

Data primer adalah data yang dikumpulkan dan diolah langsung dari obyek yang diteliti.

Data ini diperoleh dengan melakukan Focus Grup Discussion (FGD) dengan pelaku pembuatan objek penelitian.

b) Data Sekunder

Data sekunder adalah data kedua setelah sumber data primer. Data sekunder diperoleh dari berbagai literatur, situs internet, makalah, jurnal, buku - buku, dan catatan yang berkaitan erat dengan masalah yang sedang diteliti.

\section{Metode Analisis}

Metode penelitian yang digunakan dalam penelitian ini adalah :

a. Metode deskriptif

Analisis data yang terbatas pada tekhnik pengolahan datanya, seperti pengecekkan data dan tabulasi, dalam hal ini sekedar membaca tabel, grafik ataupun angka yang tersedia kemudian melakukan uraian pada penafsiran. Metode deskriptif berusaha memberikan gambaran yang cermat dan lengkap tentang objek yang diteliti. Tujuannya adalah untuk menggambarkan secara sistematis dan faktual mengenai faktor - faktor yang ada dilapangan berdasarkan teori - teori yang ada didalam literatur yang berkaitan dengan penelitian ini.

b. Metode Kuantitaif

Menggunakan Fishbone diagram. Fishbone diagram (diagram tulang ikan — karena bentuknya seperti tulang ikan) sering juga d13isebut Cause-and-Effect Diagram atau Ishikawa Diagram diperkenalkan oleh Dr. Kaoru Ishikawa, seorang ahli pengendalian kualitas dari Jepang, sebagai satu dari tujuh alat kualitas dasar (7 basic quality tools). Fishbone diagram digunakan ketika kita ingin mengidentifikasi kemungkinan penyebab masalah dan terutama ketika sebuah team cenderung jatuh berpikir pada rutinitas (Tague, 2005, p. 247). 


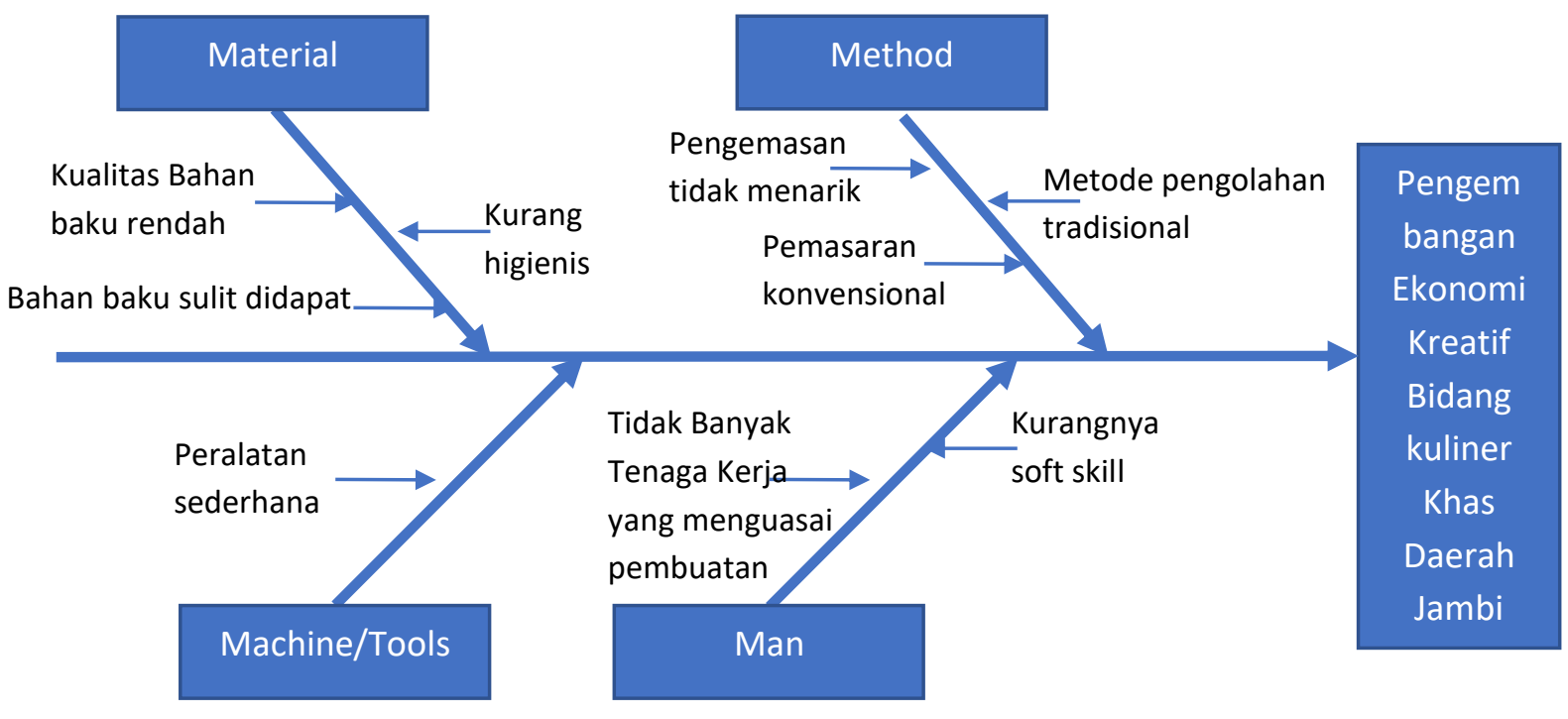

Gambar 1. Fishbone Diagram (Diagram Tulang Ikan)

Kuliner adalah hasil olahan yang berupa masakan berupa lauk-pauk dalam makanan sehari hari, penganan maupun minuman. Kuliner tidak terlepas dari kegiatan masak-memasak yang erat kaitannya dengan konsumsi makanan sehari-hari atau bisa juga makanan khas dari berbagai kota maupun provinsi. Kata kuliner merupakan unsur serapan bahasa Inggris yaitu culinary yang berarti berhubungan dengan memasak. Banyak orang yang sedang berpergian ke tempat tempat tidak lepas dari wisata kuliner. Banyak orang menyebut wisata kuliner lezat, wisata kuliner enak, wisata kuliner mantap dan lain sebagainya. Tapi bagi sebagian orang justru masih bingung, apa itu wisata kuliner. pengertian wisata kuliner bisa diartikan simple seperti jalan-jalan ke tempat dimana kita bisa menikmati makanan khas dari tempat tersebut. Untuk arti secara harfiahnya wisata adalah bepergian bersama-sama untuk memperluas pengetahuan, wawasan, dan lain sebagainya.

Sektor kuliner termasuk kedalam sektor industri kreatif. Industri kreatif kuliner sudah memiliki pasar tersendiri baik di indonesia ataupun di internasional. Sektor kuliner ini meliputi dari pembuatan kuliner khas daerah, dan juga pemasaran produk khas daerah di indonesia. Sektor kuliner di indonesia sudah memiliki pasar yang luas dan juga sudah bisa bersaing dengan pasar ritel modern. Sektor kuliner menjadi industri kreatif yang cukup menjanjikan saat ini. karena memiliki nilai ekonomis namun tetap memiliki keuntungan.

Kuliner adalah bagian yang tidak bisa dipisahkan dalam kehidupan kita sehari-hari. Dalam sektor ekonomi kreatif, kuliner merupakan salah satu sub factor yang memberikan kontribusi terbesar pada pendapatan daerah. Kuliner tidak hanya berbicara tentang makanan, bahanbahan, dan cara memasaknya, tetapi juga etika di meja makan, tata cara menghidangkan makanan, hingga kondisi di dapur. Dalam perjalanannya, kuliner terkadang dijadikan alat untuk menilai status sosial seseorang. Kuliner juga bisa bercerita tentang sejarah peradaban dan menjadi salah satu daya tarik pariwisata. Kuliner, khususnya makanan tradisoinal khas daerah, juga bisa menjadi identitas suatu suku, kota, bahkan bangsa, karena itulah kita harus menjaga keberlangsungannya. 
Penelitian ini akan memberikan model pengembangan ekonomi kreatif kuliner khas daerah Jambi melalui analisis faktor-faktor apa saja menjadi kendala dan bagaimana cara mengatasi kendala-kendala tersebut, serta apa saja yang perlu dilakukan agar kuliner khas Jambi ini tidak punah dan dapat mengalami perkembangan yang berarti. Penelitian ini akan melibatkan para pelaku pembuatan makanan khas daerah dan masyarakat yang memiliki informasi mengenai makanan tradisional khas daerah Jambi.

\section{HASIL DAN PEMBAHASAN}

\section{Hasil Yang Dicapai}

Sejauh ini data yang dibutuhkan dalam penelitian ini telah terkumpul, baik data sekunder maupun data primer. Dimana data primer diperoleh setelah melakukan survei lapangan dan Focus Discussion Group (FGD) dengan para pengusaha bisnis kuliner rumahan khas daerah Jambi. Tim peneliti telah mendapatkan berbagai informasi mengenai hal-hal apa saja yang menjadi hambatan dalam pengembangan kuliner khas daerah ini.

\section{Pemasalahan Yang Dihadapi :}

Pada umumnya permasalahan yang dihadapi oleh para pengusaha bisnis kuliner rumahan khas daerah Jambi adalah sebagai berikut :

A. Material, dimana kualitas bahan baku masih seadanya dan belum memiliki kualitas yang maksimal. Bahan baku dengan kualitas tinggi bisa diperoleh, namun mereka harus mengeluarkan biaya yang lebih besar sehingga harga jualpun harus lebih tinggi. Hal ini dikhawatirkan akan menyebabkan berkurangnya jumlah pembeli, karna selama ini segmen pasar adalah kalangan menengah kebawah.

B. Metode, metode pengolahan dan pengerjaan masih sederhana. Pengemasan masih tradisional, masih mengikut pengemasan yang turun temurun. Pemasaran yang dilakukan juga masih pada wilayah yang terbatas. Hal ini dikarenakan, daya tahan produk yang sangat singkat.

C. Peralatan, dimana masih menggunakan peralatan seadanya. Menggunakan peralatan rumah tangga sehari-hari. Bahkan banyak yang menggunakan peralatan warisan turun temurun.

D. Sumber Daya Manusia, pembuatan produk yang masih membutuhkan keahlian dan trik tertentu dan biasanya diturunkan dari generasi ke generasi. Sehingga tidak banyak yang memiliki kemampuan untuk membuat produk dengan tepat.

E. Distribusi. Daya tahan produk yang sangat pendek, membuat produk ini tidak bisa di distribusikan ke wilayah yang lebih luas.

F. Promosi. Belum adanya promosi yang secara khusus dilakukan untuk lebih memperkenalkan produk ke cakupan masyarakat yang lebih luas.

Selanjutnya data akan diolah dan dideskripsikan sesuai dengan kebutuhan penelitian.

\section{Pengembangan Ekonomi Kreatif}

Ekonomi kreatif sangat tergantung kepada modal manusia (human capital atau intellectual capital, ada juga yang menyebutnya creative capital). Ekonomi kreatif membutuhkan sumberdaya manusia yang kreatif tentunya, mampu melahirkan berbagai ide dan menterjemahkannya ke dalam bentuk barang dan jasa yang bernilai ekonomi. Sumber daya 
manusia merupakan titik sentral yang sangat penting untuk maju dan berkembang, sebagian besar usaha mikro dan usaha kecil tumbuh secara tradisional dan merupakan usaha keluarga yang turun temurun. Keterbatasan SDM baik dari segi pendidikan formal maupun pengetahuan dan keterampilannya sangat berpengaruh terhadap manajemen pengelolaan usahanya, sehingga usaha tersebut sulit untuk berkembang dengan optimal. Di samping itu dengan keterbatasan SDM nya, unit usaha relatif sulit untuk mengadopsi perkembangan teknologi baru untuk meningkatkan daya saing produk yang dihasilkannya.

Dalam era globalisasi saat ini perkembangan dunia bisnis berkembang dengan sangat pesat, salah satunya di bidang bisnis kuliner. Bisnis ini berkaitan dengan kebutuhan pangan manusia. Pangan merupakan salah satu kebutuhan dasar manusia atau basic needs. Karena termasuk kebutuhan dasar, maka pemenuhan terhadap pangan menjadi hal mutlak bagi manusia yang ingin tetap menjaga kelangsungan hidupnya. Aktivitas manusia saat ini yang begitu padat menyebabkan manusia mencari cara praktis dalam memenuhi kebutuhan pangan. Adapun cara yang ditempuh untuk memenuhi kebutuhan pangan salah satunya dengan memanfaatkan jasa kuliner.

Ruang lingkup subsektor kuliner di Indonesia dibagi ke dalam dua kategori utama jika, ditinjau dari jenis produk yang ditawarkan, yaitu jasa kuliner dan barang kuliner.Jasa kuliner (foodservice) ditinjau dari aspek persiapan dan penyajiannya, dapat dibagi ke dalam dua kategori umum, yaitu restoran dan jasa boga. Sedangkan barang kuliner yang dimaksud adalah produk makanan hasil olahan atau kemasan, khususnya kategori specialty foods. Produk makanan khusus ini semakin berkembang saat ini.

Fokus pengembangan subsektor kuliner pada industri kreatif Indonesia periode 2015-2019 adalah jasa kuliner (restoran dan jasa boga) seperti yang ditunjukkan pada gambar berikut:

BERDASARKAN JENIS

LAYANAN/PRODUK

\section{BERDASARKAN}

HASIL AKHIR

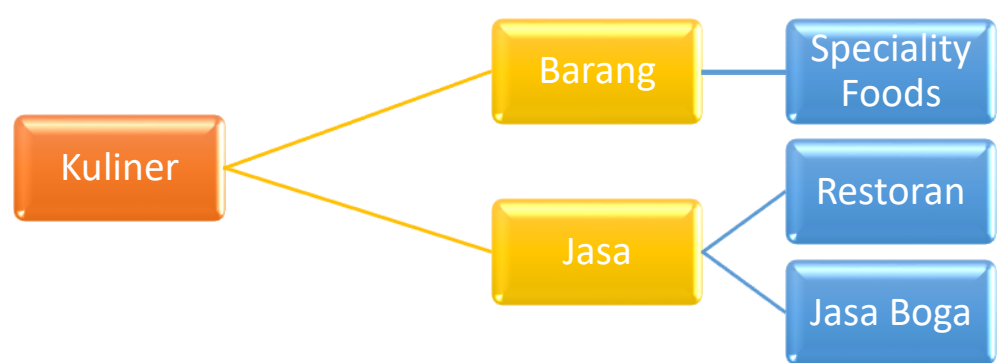

Gambar 2. Pengembangan Subsektor Kuliner Pada Industri Kreatif Indonesia

Penelitian ini menyimpulkan bahwa pengembangan industri kreatif kuliner melibatkan peran berbagai elemen yang dapat mempengaruhi pertumbuhan perekonomian Indonesia. Berdasarkan hasil simpulan diatas dapat direkomendasikan bahwa produk kuliner dapat meningkatkan perekonomian di Indonesia dengan sangat pesat. Pangan bukan lagi produk konsumsi untuk memenuhi kebutuhan biologis manusia semata. Pangan saat ini menjadi sebuah gaya hidup baru di kalangan masyarakat yang bisa meningkatkan usaha-usaha kecil menengah untuk memajukan perekonomian Indonesia 
Berdasarkan uraian diatas maka para pengusaha kuliner rumahan khas jambi sebaiknya menerapkan hal-hal sebagai berikut:

\section{1) Kreativitas.}

Kreativitas yang dimaksud adalah aspek ide baru baik melalui kreasi resep, kreasi cara pengolahan, maupun kreasi cara penyajian yang memberikan nilai tambah pada sebuah makanan dan minuman. Proses kreativitas tidak harus selalu menghasilkan sesuatu yang $100 \%$ baru, namun bisa berupa pengembangan dari sesuatu yang sudah ada sehingga memiliki nilai jual yang lebih tinggi dan lebih menarik di pasar.

\section{2) Estetika.}

Estetika yang dimaksud adalah aspek tampilan dari sebuah makanan dan minuman dengan meperhatikan unsur keindahan sehingga menjadikan produk kuliner tersebut memiliki nilai lebih dan mampu menggugah selera konsumen untuk menikmatinya.

3) Tradisi.

Tradisi yang dimaksud adalah sesuatu yang telah dilakukan sejak lama dan menjadi bagian dari kehidupan suatu kelompok masyarakat yang berkaitan dengan kebiasaan dalam mengolah dan mengonsumsi makanan dan minuman. Hal yang paling mendasar dari tradisi adalah adanya informasi yang diteruskan dari generasi ke generasi baik tertulis maupun lisan, karena tanpa adanya proses ini, suatu tradisi dapat punah. Unsur tradisi ini sangat penting dalam menjaga warisan budaya kuliner.

\section{4) Kearifan Lokal.}

Kearifan lokal yang dimaksud adalah identitas suatu daerah berupa kebenaran yang telah tertanam dalam suatu daerah. Berkaitan dengan kuliner, kearifan lokal yang merupakan kebijaksanaan manusia yang bersandar pada filosofi nilai-nilai, etika, caracara, dan perilaku, melembaga secara tradisional, akan membentuk karakter kuliner suatu daerah. Karakter kuliner tersebut harus mampu diangkat dan dikenalkan kepada masyarakat luas.

Pengembangan Ekonomi Kreatif kuliner khas daerah Jambi pada hakekatnya merupakan tanggungjawab bersama antara pemerintah dan masyarakat. Dengan mencermati permasalahan yang dihadapi, maka kedepan perlu diupayakan hal-hal sebagai berikut :

1. Penciptaan Iklim Usaha yang Kondusif. Pemerintah perlu mengupayakan terciptanya iklim yang kondusif, antara lain dengan mengusahakan ketenteraman dan keamanan berusaha serta penyederhanaan prosedur perijinan usaha, keringanan pajak dan sebagainya.

2. Bantuan Permodalan. Pemerintah perlu memperluas skim kredit khusus dengan syaratsyarat yang tidak memberatkan bagi UKM, untuk membantu peningkatan permodalannya, baik itu melalui sektor jasa finansial formal, sektor jasa finansial informal, skema penjaminan, leasing dan dana modal ventura.

3. Perlindungan Usaha. Jenis-jenis usaha tertentu, terutama jenis usaha tradisional seperti kuliner khas daerah Jambi ini, yang merupakan usaha golongan ekonomi lemah, harus mendapatkan perlindungan dari pemerintah, baik itu melalui undang-undang maupun peraturan pemerintah yang bermuara kepada saling menguntungkan (win-win solution). 
4. Pengembangan Kemitraan. Perlu dikembangkan kemitraan yang saling membantu antara UKM, atau antara UKM dengan para pengusaha di dalam negeri maupun jika memungkinkan di luar negeri. Disamping itu juga untuk memperluas pangsa pasar dan pengelolaan bisnis kuliner yang lebih efisien. Dengan demikian UKM akan mempunyai kekuatan dalam bersaing dengan pelaku bisnis lainnya.

5. Pelatihan. Pemerintah perlu meningkatkan pelatihan bagi UKM khususnya pada industri kuliner khas daerah Jambi. Meningkatkan aspek kewiraswastaan, manajemen, administrasi dan pengetahuan serta keterampilannya dalam pengembangan usahanya. Disamping itu juga perlu diberi kesempatan untuk menerapkan hasil pelatihan di lapangan untuk mempraktekkan teori melalui pengembangan kemitraan rintisan.

6. Membentuk Lembaga Khusus. Perlu dibangun suatu lembaga yang khusus bertanggung jawab dalam mengkoordinasikan semua kegiatan yang berkaitan dengan upaya penumbuh kembangan UKM dan juga berfungsi untuk mencari solusi dalam rangka mengatasi permasalahan baik internal eksternal yang dihadapi oleh UKM khususnya yang bergerak di industri kuliner khas daerah Jambi.

7. Memantapkan Asosiasi. Asosiasi yang telah ada perlu diperkuat, untuk meningkatkan perannya antara lain dalam pengembangan jaringan informasi usaha yang sangat dibutuhkan untuk pengembangan usaha bagi anggotanya.

8. Mengembangkan Promosi. Mengembangkan promosi guna lebih mempercepat proses kemitraan antara UMKM dengan usaha besar diperlukan media khusus dalam upaya mempromosikan produk-produk kuliner khas daerah Jambi yang dihasilkan. Mengembangkan kerja sama yang setara dan koordinasi yang serasi antara pemerintah dengan UMKM untuk mengiventarisir berbagai isu-isu mutakhir yang terkait dengan perkembangan usaha kuliner khas daerah Jambi.

\section{Luaran Yang Dicapai}

Laporan penelitian ini nantinya diharapkan akan masuk ke Prosiding, Artikel ilmiah atau Jurnal Humaniora yang ada di Universitas Jambi, dan jika memungkinkan pada jurnal nasional terakreditasi yang ada di Indonesia.

\section{KESIMPULAN DAN SARAN}

\section{Kesimpulan}

Masih banyak permasalahan yang secara umum dihadapi dalam mengembangkan ekonomi kreatif pada umumnya dan oleh pengusaha industri kuliner rumahan khas daerah Jambi pada khususnya. Namun permasalahan ini, seharusnya bisa diatasi melalui pengembangan ekonomi kreatif dan juga melalui kerjasama yang menguntungkan dengan berbagai pihak, terutama kerjasama dan dukungan dari pemerintah Provinsi Jambi.

\section{Saran}

Para pengusaha industri kuliner rumahan khas daerah Jambi sudah saatnya untuk meningkatkan kualitas produknya ke level yang lebih tinggi pada berbagai aspek dan juga melalui penerapan ekonomi kreatif, sehingga nantinya industri kuliner khas daerah Jambi memiliki nilai jual yang lebih tinggi dan pangsa pasar yang lebih luas. 


\section{DAFTAR PUSTAKA}

Endang Sarijani, 2014. Peran kreatifitas dan inovasi pelaku usaha dalam diversifikasi produk kuliner pada kedai steak and chicken di kabupaten Magetan, Program studi magister pendidikan ekonomi FKIP Universitas 11 Maret Surakarta.

Howkins, J, 2001. The Creative Economy : How people make money from ideas. LondonEngland. Penquin books LTd 80 Strand.

LB.Ruth Florida, 2015. Strategi pengembangan usaha kuliner di kota Malang berbasis Ekonomi Kreatif, ESP_Vol.7, No.1 Maret 2015. ISSN 2086-1575 FE Universitas Negeri Malang.

Mandra Lazuardi, Mochamad Sandy Tiady, 2015. Rencana Pengembangan Kuliner Nasional 2015 - 2019. ISBN 978 - 602 - 72367 - 5 - 2. PT. Republik Solusi.

Mari Elka Pangestu, 2008a. Buku 1 : Rencana Pengembangan Ekonomi Kreatif 2009 : 2015 Jakarta. Kelompok Kerja Indonesia Design Power : Departemen Perdagangan RI

Mari Elka Pangestu, 2008b. Buku 2 : Rencana Pengembangan 14 Subsektor Industri Kreatif 2009 : 2015 Jakarta. Kelompok Kerja Indonesia Design Power : Departemen Perdagangan RI

Muzakar Isa, 2015. Model penguatan kelembagaan industri kreatif kuliner sebagai upaya pengembangan ekonomi daerah, FEB Universitas Muhamadiyah Surakarta.

Rosmawaty Sidauruk, 2013. Peningkatan peran pemerintah daerah dalam rangka pengembangan ekonomi kreatif di Provinsi Jawa Barat, Badan Penelitian dan Pengembangan Kementrian Dalam Negri .

Suparwoko, Ir. MURP PhD, 2015.Makalah Pengembangan Ekonomi Kreatif Sebagai Penggerak Industri Pariwisata Pengembangan Ekonomi Kreatif Sebagai Penggerak Industri Pariwisata. Jurusan Arsitektur, Fakultas Teknik Sipil dan Perencanaan. Universitas Islam Indonesia - Yogyakarta.

Wayan Nanda Krishna, dkk, 2015.Pengembangan Ekonomi Kreatif, studi kasus produk kuliner sego njamoer, Institut Tekhnologi 10 Nopember. 